\title{
Evidence of Diel Vertical Migration of Mesopelagic Sound-Scattering Organisms in the Arctic
}

\section{OPEN ACCESS}

Edited by:

Ricardo Serrão Santos, University of the Azores, Portugal

Reviewed by:

Kim Last,

Scottish Association for Marine

Science, United Kingdom

Michael Arthur St. John,

National Institute of Aquatic

Resources, Technical University of

Denmark, Denmark

Tracey T. Sutton,

Nova Southeastern University,

United States

${ }^{*}$ Correspondence:

Harald Gjøsæter

harald.gjosaeter@imr.no

Specialty section:

This article was submitted to Deep-Sea Environments and Ecology, a section of the journal

Frontiers in Marine Science

Received: 11 May 2017 Accepted: 06 October 2017 Published: 23 October 2017

Citation:

Gjøsæter H, Wiebe PH, Knutsen T and Ingvaldsen RB (2017) Evidence of Diel Vertical Migration of Mesopelagic

Sound-Scattering Organisms in the

Arctic. Front. Mar. Sci. 4:332

doi: 10.3389/fmars.2017.00332

\author{
Harald Gjøsæter ${ }^{1 *}$, Peter H. Wiebe ${ }^{2}$, Tor Knutsen ${ }^{3}$ and Randi B. Ingvaldsen ${ }^{4}$ \\ ${ }^{1}$ Institute of Marine Research, Research Group Demersal Fish, Bergen, Norway, ${ }^{2}$ Woods Hole Oceanographic Institution, \\ Biology Department, Woods Hole, MA, United States, ${ }^{3}$ Institute of Marine Research, Research Group Plankton, Bergen, \\ Norway, ${ }^{4}$ Institute of Marine Research, Research Group Oceanography and Climate, Bergen, Norway
}

While sound scattering layers (SSLS) have been described previously from ice-covered waters in the Arctic, the existence of a viable mesopelagic community that also includes mesopelagic fishes in the Arctic has been questioned. In addition, it has been hypothesized that vertical migration would hardly exist in these areas. We wanted to check if deep scattering layers (DSLS) was found to the west and north of Svalbard $\left(79^{\circ} 30^{\prime} \mathrm{N}-82^{\circ} 10^{\prime} \mathrm{N}\right)$ during autumn 2015 , and if present; whether organisms in such DSLs undertook vertical migrations. Our null hypothesis was that there would be no evidence of diel vertical migration. Multi-frequency acoustic observations by hull mounted echo sounder $(18,38$, and $120 \mathrm{kHz}$ ) revealed a DSL at depths $\sim 210-510 \mathrm{~m}$ in areas with bottom depths exceeding $\sim 600 \mathrm{~m}$. Investigating eight geographical locations that differed with respect to time periods, light cycle and sea ice conditions, we show that the deeper layer of DSL displayed a clear ascending movement during night time and a descending movement during daytime. The high-light weighted mean depth (WMD) (343-514 m) with respect to backscattered energy was statistically deeper than the low-light WMD (179-437 m) for the locations studied. This behavior of the DSL was found to be consistent both when the sun was continuously above the horizon and after it started to set on 1 September, and both in open water and sea ice covered waters. The WMD showed an increasing trend, while the nautical area backscattering strength from the DSL showed a decreasing trend from south to north among the studied locations. Hydrographic observations revealed that the diel migration was found in the lower part of the north-flowing Atlantic Water, and was disconnected from the surface water masses above the Atlantic Water during day and night. The organisms conducting vertical migrations were studied by vertical and oblique hauls with zooplankton nets and pelagic trawls. These data suggest that these organisms were mainly various mesopelagic fishes, some few larger fishes, large zooplankton like krill and amphipods, and various gelatinous forms.

Keywords: Arctic Ocean, deep scattering layer, diel vertical migration, mesopelagic organisms, acoustics

\section{INTRODUCTION}

Deep Scattering Layers (DSLs) at depths from about $200 \mathrm{~m}$ to about $1,000 \mathrm{~m}$, are a global phenomenon (Hays, 2003; Irigoien et al., 2014). The term DSL comes from the fact that these layers were first discovered by acoustic methods in 1942 (Eyring et al., 1948); and can be defined as a group of organisms which scatter sound and appear as a continuous layer on an echo sounder where 
organisms cannot be individually resolved (Tont, 1976). The DSLs normally consists of a variety of organisms, mostly zooplankton and small fish, but due to their almost universal phenomenon, the composition of a DSL may differ from area to area (Tont, 1976). For the same reason, the depth ranges and the extent of vertical migration of a DSL may also vary from area to area.

Sound scattering layers (SSLs) have been detected and described in the Central Arctic Ocean by echo sounders operating at 12 and $100 \mathrm{kHz}$ mounted at the ice station Fletcher's Ice Island, T-3 (Hunkins, 1965; Kutschale, 1969; Hansen and Dunbar, 1971). These observations were made within the upper $200 \mathrm{~m}$ of the water column, and might not be called true DSLs in the current meaning of the word, although the authors themselves use this notation. The organisms producing the scattering layers were speculated by Kutschale (1969) to be siphonophores, but Hansen and Dunbar (1971) found that a thin layer at $50 \mathrm{~m}$ detected at $100 \mathrm{kHz}$ was composed of the pteropod Spiratella (now Limacina) helicina and a deeper layer detected on both frequencies was thought to be due to Arctic cod (Arctogadus glacialis).

DSLs are well described for many oceanic or deep fjordic areas in the North Atlantic (Melle et al., 1993; Magnússon, 1996; Torgersen et al., 1997; Kaartvedt et al., 1998; Knutsen and Serigstad, 2001; Sigurðsson et al., 2002; Kaartvedt, 2008; Pepin, 2013). Normally, all or some of the organisms in these layers move toward the surface at dusk and return to daytime depths at dawn (Hays, 2003). This diel vertical migration of the DSLs is thought to maximize feeding success of the mesopelagic organisms while minimizing their risk of being eaten (Hays, 2003; Kaartvedt, 2008). Whatever reason for this migration behavior, the cue regulating it is thought to be light (Clarke, 1971; Forward, 1976; Lampert, 1989; Brierley, 2014).

The light regime at high latitudes varies considerably among seasons, in contrast to the light regimes found at lower latitudes, which has almost total darkness during night and bright daylight throughout the year. During winter, almost total darkness dominates day and night, since the sun stays continuously below the horizon, while during summer the sun stays continuously above the horizon. Further, the incoming sunlight depends not only on the duration of daylight, but also on cloud cover, including fog frequently occurring in polar regions, and the sun angle (the height of the sun above and below horizon). The latter affects both the sunlight intensity above sea surface (more light is attenuated between the top of the atmosphere and the surface with low sun angles), as well as how much of the incident sunlight that penetrates the air-water surface and enters the ocean. Thus, there will be daily variation in light despite the sun being constantly above the horizon.

Various organisms inhabiting the DSL are likely to have different sensitivities to light and are affected to varying degrees by the changes in the light regime (Clarke, 1971; Kampa, 1971; Roe, 1983; Frank and Widder, 1999). This is clearly seen in many areas where a fraction of the DSL moves toward the surface during night while some organisms either remain at their daytime depths or migrate only to a small degree (Roe et al., 1984; Plueddemann and Pinkel, 1989; Wiebe et al., 1992; Heywood,
1996). However, it should also be noted that the ambient light regime is not only affected by the surface irradiance and water column optical properties, but also bioluminescence (cf. Cronin et al., 2016), that can be particularly important during the Arctic winter. Recently published work from this region show that some organisms respond to even very weak variations in light level, and mass-vertical migration during Arctic winter driven by moonlight has been documented (Cohen et al., 2015; Last et al., 2016). However, these studies have focused on zooplankton in the upper $50 \mathrm{~m}$.

An increasing number of studies have lately addressed how climate change and particularly loss of sea ice and ocean warming can affect the ecosystem of the Arctic Ocean (see Wassmann and Reigstad, 2011; Varpe et al., 2015). With reduced areal ice cover and ice thickness, light penetration is suggested to be a crucial factor for the primary producers like phytoplankton and ice algae (Mundy et al., 2009; Nicolaus et al., 2012, 2013). Furthermore, a modified-light regime also has consequences for the secondary producers that directly depend on algae as their primary-food source (Ji et al., 2013). Light is also an important factor for many deeper living organisms including those inhabiting the DSL. In the high-Arctic, the continuous light of the midnight sun may prevent DSL animals from vertically migrating to feed in the productive surface waters. This is particularly evident for mesopelagic fishes (Kaartvedt, 2008), but other types of organisms that normally constitute the DSL elsewhere in the North Atlantic could also be affected (see Melle et al., 1993; Torgersen et al., 1997; Kaartvedt et al., 1998; Sigurðsson et al., 2002).

Factors that restrict mesopelagic organisms' diel vertical migration and their potential feeding in the near surface waters, will also affect the vertical flux of organic matter that initially depends primarily on primary production and the types of zooplankton grazers and the magnitude of feeding intensity in the upper layers (Wassmann, 1998; Wassmann and Reigstad, 2011). Thus, an important pathway to bring organic matter to the deeper part of the water column could be throttled, preventing mesopelagic species from living in these areas since a 24-h light regime may constrain light-dependent vertical migration of such species, which gave rise to the "photoperiod constraint hypothesis" (Kaartvedt, 2008). However, few studies of the mesopelagic fauna in the deep oceans at high latitudes exist, so neither the abundance nor the migration behavior of mesopelagic fishes and plankton at high latitudes are well known. Also, the consequences of a changing climate and light regime and how it might impact species and trophic interactions is presently another important unknown.

The results from the SI_ARCTIC 2014 and SI_ARCTIC 2015 surveys revealed that although less substantial in terms of integrated acoustic backscatter than further south, a DSL was found in the Northern Fram Strait and further to the north of Svalbard at latitudes between 79 and $82^{\circ} \mathrm{N}$ (Knutsen et al., 2017; this manuscript). This finding corroborates previous observations that scattering layers are present in high latitudes, at least in summer (Hunkins, 1965; Kutschale, 1969; Hansen and Dunbar, 1971). Here, we utilize data from the SI_ARCTIC 2015 survey to investigate whether this DSL performs a diel 
vertical migration during summer and if differences in diel vertical migration can be observed when contrasting regions with fractional sea ice vs. open water, and regions experiencing the midnight sun vs. regions where the midnight-sun period has ended. The null hypothesis is that during continuous daylight there is no evidence of diel vertical migration. We also describe the composition of the DSL to establish the presence of mesopelagic fishes.

\section{MATERIALS AND METHODS}

This study is based on the SI_ARCTIC 2015 survey (Ingvaldsen et al., 2016) conducted with RV Helmer Hanssen from 19 August to 7 September 2015 in the eastern Fram Strait and north of Svalbard (Figure 1). At eight deep-water locations, the ship stayed within a relatively small area for almost $24 \mathrm{~h}$ or more allowing for continuous observations of the mesopelagic community at that location for a sufficient time to determine whether the DSL undertook diel vertical migration (marked in Figure 1). The eight locations differed with respect to sea ice concentration and midnight-sun conditions, allowing for investigating diel vertical migration in contrasting regimes.

\section{Environmental Data}

Visible light above sea level on a continuous basis was measured with a LI-COR Model LI-1400 data logger with a LI-210SA

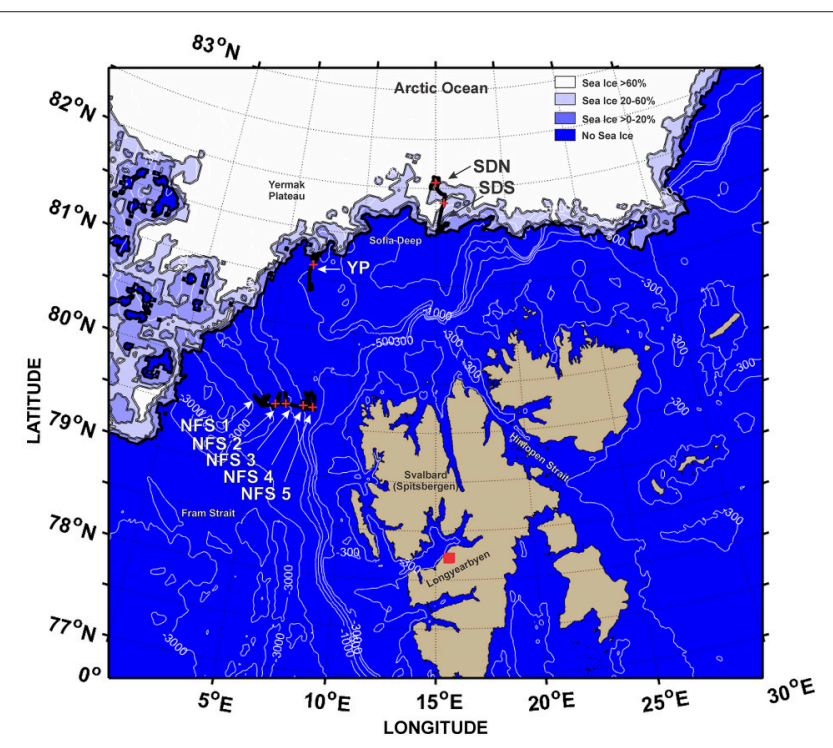

FIGURE 1 | Cruise tracks of R/V Helmer Hanssen during the SI_ARCTIC 2015 cruise. Locations where day/night differences in the depth of the weighted mean acoustics data in the mesopelagic layer were compared are shown as black lines and + show location of CTD casts used in this study. The arrows point to eight locations: Sofia Deep N (SDN), Sofia Deep S (SDS), Yermak Plateau (YP), Northern Fram Strait 1 (NFS 1), Northern Fram Strait 2 (NFS 2), Northern Fram Strait 3 (NFS 3), Northern Fram Strait 4 (NFS 4), and Northern Fram Strait 5 (NFS 5). The figure uses the AMSR2-Based Sea Ice Concentrations on 30 August 2015 when the Helmer Hansen was conducting work at the ice edge. The Sea Ice data were obtained from ftp://ftp-projects. cen.uni-hamburg.de/seaice/AMSR2/3.125km/ (Kaleschke and Tian-Kunze (2016). See Beitsch et al. (2014) for a description of the analysis procedures.
Photometric Sensor (Figure 2). The sensor was located above the bridge on the upper deck of the ship where minimal shading could occur as the ship moved around. A fraction of the light incident on the sea surface is reflected, and the degree of reflection depends on the solar elevation angle. To obtain estimates of the amount of visible light entering the ocean at the time and location of the eight study locations, theoretical values of solar elevation angle were calculated using the NOAA Solar Calculator (http://www.esrl.noaa.gov/gmd/ $\mathrm{grad} /$ solcalc/calcdetails.html) and the visible light penetrating into the upper waters was calculated using So* $\cos (90$-solar elevation angle), where So is the solar constant $\mathrm{So}=1,360 \mathrm{Wm}^{-2}$ (Figure S1). The presence of sea ice; ice and snow cover thickness and possibly air-filled brine channels (Lund-Hansen et al., 2015), will considerably affect light transmittance to the water column below. Thus, the amplitudes of the light variations in the surface layers at locations affected by sea ice will be substantial less than shown in Figure 2. Another issue not included in such estimates is the light attenuation by depth, which depend on several factors like the amount of Chlorophyll $\boldsymbol{a}$ and CDOM in the water-column (cf. Kowalczuk et al., 2017). These parameters are of prime importance for the in-situ light attenuation and vary both regionally within the study region as well as seasonally (Kowalczuk et al., 2017). However, the daily variation of these parameters at a given location is expected to be small.

Temperature and salinity was measured using a Seabird 911+ CTD. The CTD was equipped with an oxygen sensor (SBE 43) and Seapoint sensors for measuring relative distribution of fluorescence and turbidity. Water mass characteristics (temperature, salinity, density, oxygen) were included to investigate whether these parameters could influence the vertical extension of the diel vertical migration (see e.g., Klevjer et al., 2016), while fluorescence and turbidity in the epipelagial were included to explore for differences in horizontal light attenuation among the locations (see e.g., Kaartvedt et al., 1996). Chlorophyll $\boldsymbol{a}$ has by a recent study been found to give a good representation of light absorption in open leads and under ice water column in this region (Kowalczuk et al., 2017).

\section{Biological Data Collection}

Samples of fish, micronekton, zooplankton, and phytoplankton were collected with a variety of net systems including the Åkra trawl (Valdemarsen and Misund, 1995), the MIK-Ring Net (Munk, 1993; ICES, 2013), and the Macroplankton trawl (Melle et al., 2006; Wenneck et al., 2008). A Multisampler (an opening and closing device with three net bags and codends, Wenneck et al., 2008) was attached to the Åkra trawl for three of the hauls, allowing the catches from up to three depth intervals during each haul to be separated. The MIKRing Net was towed horizontally in the DSL, either in a Wshaped fashion or including the DSL during a single net oblique tow (Wiebe et al., 2015) to provide a quantitative sample of the larger macrozooplankton associated with the DSL. One haul with a Macroplankton trawl was also made in the mesopelagic layer. The trawls were used to obtain a qualitative and semiquantitative understanding of larger micronekton and fishes that were present in the acoustic scattering structures observed. 


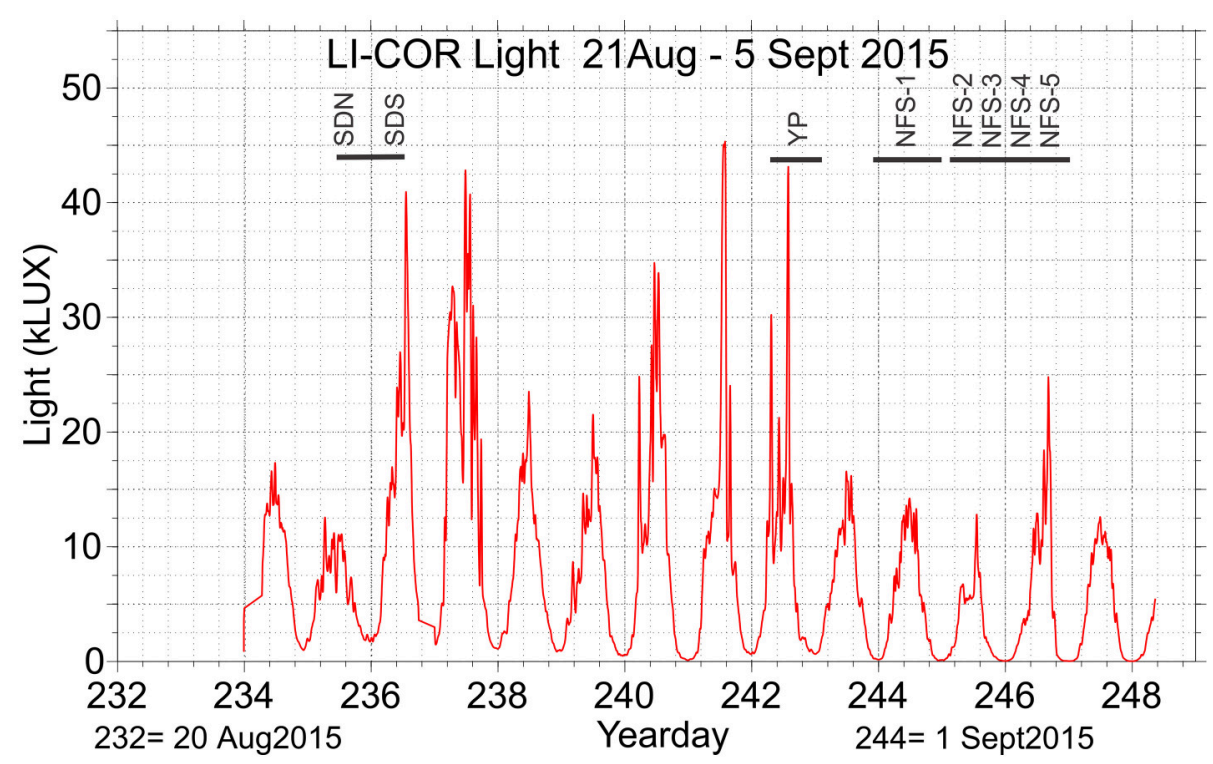

FIGURE 2 | Light levels determined from a LI-COR light data logger recorded during SI_ARCTIC 2015 survey. The eight named time periods where the diel vertical migration studies were conducted are indicated by the black lines above the light data [Sofia Deep N (SDN), Sofia Deep S (SDS), Yermak Plateau (YP), Northern Fram Strait 1 (NFS 1), Northern Fram Strait 2 (NFS 2), Northern Fram Strait 3 (NFS 3), Northern Fram Strait 4 (NFS 4), and Northern Fram Strait 5 (NFS 5 )].

For the Åkra trawl catches total numbers and wet weight was obtained for each taxonomic group or species being determined. Lengths were recorded for all specimens in the catch, while in addition weight, maturity stage, and stomach content were determined for a subsample of the fish catch. Another subsample of the invertebrate part of the catch was worked up to species or genus if possible or to coarser groups like "Amphipoda" or "Euphausiacea" and their numbers and weights determined $( \pm 0.1 \mathrm{~g})$. The Macroplankton trawl and MIK net catches were worked up in a similar way after first determining total wet weight of catch (kg). Normally, all larger fish and gelatinous zooplankton were identified to nearest possible taxon, counted, and their wet weight measured. Because of the scarcity of fish caught by the two latter types of gear, individual lengths and wet weights were normally obtained. The remaining invertebrate catch was subsampled and worked up to nearest possible taxon and their numbers and wet weight determined $( \pm 0.1 \mathrm{~g})$. Catches from $\AA$ kra trawl hauls were standardized to $\mathrm{kg} \mathrm{nmi}^{-1}$. The Macroplankton trawl and MIK net catches were standardized to $\mathrm{g} \mathrm{m}^{-3}$ using a computed haul volume filtered.

\section{Acoustic Data Collection}

Acoustic data for estimation of the distribution and amount of backscatter from the DSL (reverberation from scatterers near the surface that were clearly separated from the DSL was not included) were collected with calibrated EK60 split beam echo sounder systems at the acoustic frequencies 18, 38, and $120 \mathrm{kHz}$ all operated at $1 \mathrm{~ms}$ pulse duration. The transducers were mounted on a protruding instrument keel with transducer faces $\sim 3 \mathrm{~m}$ below the hull, usually $\sim 8.5 \mathrm{~m}$ below the sea surface. The echo integrator threshold in terms of volume backscattering strength (Sv) in $\mathrm{dB}$ was set to $-82 \mathrm{~dB}$ re $1 \mathrm{~m}^{-1}$ (MacLennan et al.,
2002). Weaker backscattering than this set threshold will thus not be included in the density estimation. In the upper $\sim 200 \mathrm{~m}$, where the signal/noise ratio on the $120 \mathrm{kHz}$ echo sounder is above acceptable levels, the frequency response was based on all three frequencies, while below this depth, only 18 and $38 \mathrm{kHz}$ were considered. The $38 \mathrm{kHz}$ frequency was finally used to determine the distribution and backscattered intensity of the DSL.

The noise level on the various echo sounder frequencies was measured in deep water at several vessel speeds, as well as with the propeller disconnected during stationary measurements. The recorded noise level at 10.8 knots were $-137,-161$, and -152 $\mathrm{dB}$ re $1 \mathrm{~W}$, as directly measured by the Simrad EK60 in passive mode at 18,38 , and $120 \mathrm{kHz}$ systems. During station work, when the propeller was still rotating, but with zero pitch, the noise levels were $-144,-164$, and $-155 \mathrm{~dB}$ re $1 \mathrm{~W}$. The noise levels were also measured in passive mode at $8,6,4$, and 2 knots. These noise levels enable measurements of a weak scattering, corresponding to $\mathrm{Sv}=-80 \mathrm{~dB}$ re $1 \mathrm{~m}^{-1}$, with $10 \mathrm{~dB}$ signal to noise ratio at about $700 \mathrm{~m}$ range at $18 \mathrm{kHz}, 800 \mathrm{~m}$ range at $38 \mathrm{kHz}$, and $200 \mathrm{~m}$ range at $120 \mathrm{kHz}$. The 18 and $38 \mathrm{kHz}$ had more noise at unfavorable propeller pitch, for example at 3-6 knots, while the $120 \mathrm{kHz}$ system was not affected by propeller noise, and had the same sensitivity at all vessel speeds. Since the lower limit of the DSL was mostly found above $600 \mathrm{~m}$, and the scattering from weak scatterers approaching the lower integrator threshold would be observable much deeper (750-800 m) both during survey speed 10-11 knots and during stationary vessel operation, we concluded that the observed noise level was acceptable for this study.

Multi-frequency scrutinization and target strength analysis were conducted daily with the Large Scale Survey System (LSSS) post-processing system (Korneliussen et al., 2006, 2016), which 
also was used for exporting files for subsequent analysis. The interpretations were made per standard procedures where the total backscatter was split into target categories (see ICES, 2015; Korneliussen et al., 2016). However, for studying the vertical movement of the DSL, the total backscattering values were used, that means that we did not rely on the values allotted to the various acoustic categories when calculating the WMD of the DSL. The processing involved manual removal of unwanted acoustic noise from e.g., trawl sensors during trawl operations. The weather conditions were favorable to very good during the entire survey, and since the vessel has a drop instrument keel, air bubble attenuation or bubble drop-out were practically absent. Cavitation noise only occurred when the vessel abruptly was stopped for a station and other acoustic instrumentation, like the ADCP, was synchronized by an external trigger system, leaving the EK60 as a master. The scrutinized acoustic backscattering data in the echo sounder output were in the form of $s_{A}$, Nautical area scattering coefficient (NASC) in standard units; $\left(\mathrm{m}^{2} \mathrm{nmi}^{-2}\right.$ MacLennan et al., 2002). They were integrated to 10-m depth bins from below the hull mounted $38 \mathrm{kHz}$ transducer ( $\sim 15 \mathrm{~m}$ depth) to below $700 \mathrm{~m}$. For data obtained during station work, the following work-flow was applied; the processing was done in ping mode, were all pings were shown and used for density estimation, and the selection of at least one valid 10-min period within each hour was done manually due to the variable noise levels during station work. Specifically, the echogram over $1 \mathrm{~h}$ period, covering $1,800-3,600$ pings was analyzed in ping mode, and scrutinized for noise; removing manually echoes from the CTD, the TS-Probe or vertically deployed nets. Then, a measurement box of 10 min' duration and $800 \mathrm{~m}$ depth were placed in a noise-free area of the echogram, while the rest of the echogram was deleted from the analysis using the "exclude region" tool. So, for each hour, one noise-free 10-min period was selected as a representative subset of acoustic data for that particular time-period. This density estimation was then based on 300-600 ping averages, depending on the bottom depths, and hence ping rates, in the area.

\section{Methods}

Acoustic recordings at $38 \mathrm{kHz}$ from eight locations were analyzed from 23-24 August, 30 August, 1 September, and 2-3 September (Figure 1). The first two recordings (23-24 August) were obtained from the Sofia Deep in waters with $20-80 \%$ sea ice coverage, the third at the Yermak Plateau (30 August) in icefree waters, but close to the ice edge, while the last five (1 and 2-3 September) were recorded in open water further south on a transect in the northern Fram Strait. The WMD of the DSL was used to determine the mean depth of the DSL taking into account the acoustic backscattering for each depth bin. For each time interval WMD was computed using the following equation:

$$
W M D=\sum_{j=1}^{N} z_{j} s_{A_{j}}(D S L) / \sum_{j=1}^{N} s_{A_{j}}(D S L)
$$

where $z_{j}$ is the depth of depth bin $j, s_{A j}$ is the NASC value for that depth interval, and $N$ is the number of depth intervals.

The LI-COR light sensor data were used to examine the relationship between the visible light on the sea surface ("surface irradiance"; Figure 2) and movements of the DSL. A boxplot of the light data was used to determine the median light level and the 25th and 75th percentiles for each time period (or part selected for analysis) within the eight acoustic measurement events. The times where light levels were at or below the 25th percentile or at or above the 75th percentile were used to determine the times used to select the NASC data for comparison of the vertical distribution of between low-light levels and high-light levels. This procedure was used to avoid the transition periods in light levels. The WMD in the four acoustic records was examined statistically. Paired $t$-tests were used to compare high-light and low-light depths.

\section{RESULTS}

\section{Light Conditions}

The level of visible light measured on the upper deck during the whole survey showed that there was substantial 24 -h variation in light level at these latitudes (Figure 2). The solar elevation based on latitude and time of the locations showed that the height of the sun varied about $20^{\circ}$ within a $24-\mathrm{h}$ cycle (Figure S1). The elevation changes resulted in only a portion of the observed $24-h$ variation in the observed visible light at the sea surface. The variation in maximum light between days was even larger due largely to changes in cloud cover. The differences in solar angle among the localities were small, although the sun was below horizon about $5 \mathrm{~h}$ during the last five acoustic recording events in northern Fram Strait (1st and 2-3rd September, Table 1).

\section{Acoustic Backscattering and Vertical Location of the DSL}

The acoustic backscattering from the DSL was generally low, with $\mathrm{s}_{\mathrm{A}}$ from about $5 \mathrm{~m}^{2} \mathrm{nmi}^{-2}$ at the northernmost station to about $25-30 \mathrm{~m}^{2} \mathrm{nmi}^{-2}$ at the southernmost station (Table 1). The low $\mathrm{s}_{\mathrm{A}}$ is supported by the sparseness of the trawl catches in the DSL (see next section). At Sofia Deep S (23 August), the DSL vertical extent was from about $150 \mathrm{~m}$ to about $720 \mathrm{~m}$ (Tables 1, 2), and the average WMD was $392 \mathrm{~m}$ depth (Table 1, Figure 3A). At Sofia Deep N (24 August), the vertical extent of the DSL and the average WMD was rather similar (Figure 3B). At the Yermak Plateau (30 August), total vertical extent of the DSL was from 180 to $660 \mathrm{~m}$, the $s_{A}$ was 7.4 and the average WMD $464 \mathrm{~m}$ (Tables 1, 2, Figure 3C). In the westernmost part of the northern Fram Strait (1-2 September), the DSL occurred from 100 to $210 \mathrm{~m}$ to about $510-620 \mathrm{~m}$ (Tables 1, 2, Figure 3D). For the rest of the northern Fram Strait section (2-3 September), the vertical extent of the DSL was broader and upper limit was even shallower, from about 70-80 to 510-610 m depth (Tables 1, 2, Figure 3E-H). The $s_{A}$ in this region was from 26 to $32 \mathrm{~m}^{2}$ $\mathrm{nmi}^{-2}$ and the average WMD was from 280 to $325 \mathrm{~m}$. When looking at the study region as a whole, all locations demonstrate a DSL at depths of 210-510 m (Table 1). However, the upper and lower limits of the DSL show considerable variation with shallowest upper DSL limit at $70 \mathrm{~m}$ and deepest lower DSL limit at $720 \mathrm{~m}$. 


\section{Characterization of the DSL from Trawl and Net Catches}

An analysis of the catch in the Åkra trawl hauls set in the mesopelagic layer revealed that a few fish and plankton groups were caught at depths between 300 and $600 \mathrm{~m}$ over bottom depths of more than $900 \mathrm{~m}$ (Table S1). Although the Multisampler was attached to the trawl, the catch of a Cyanea capillata in a tow from 345 to $434 \mathrm{~m}$, a species normally encountered in more shallow water, suggests that organisms might in some cases be retained in the main part of the trawl and enter the Multisampler codend at a later stage. The catch composition should, therefore, be interpreted with some caution. The species Arctozenus risso, Boreogadus saida, and Sebastes mentella were identified, and among lanternfishes Benthosema glaciale and Lampanyctus macdonaldi were present. Among plankton, the krill species Meganyctiphanes norvegica and Thysanoessa inermis, the amphipods Themisto libellula and Gammarus wilkitzkii, the deep-water shrimp Sergestes arcticus, and the Scyphomedusae Perifylla perifylla and C. capillata were identified to species level. The catches targeting the DSL were extremely sparse (Table S1), probably reflecting the low concentration of organisms at these depths, but also a result of smaller organisms passing through the large mesh trawl netting, which is primarily designed to catch fish.

The MIK and Macroplankton trawl catches (Table S2) show that key macrozooplankters were Hydromedusae of different species, of which Aglantha digitale was particularly important, but in deeper tows the arrow worms (Chaetognatha) became more important. Another group of importance in terms of standardized catch weight, but also certainly underestimated due to the Macroplankton trawl mesh size $[\sim 4 \mathrm{~mm}]$, was the large copepods (Calanus hyperboreus, Paraeuchata sp). Groups known to have a higher swimming capacity, (the amphipods Themisto abyssorum and T. libellula and the krill M. norvegica, Thysanoessa longicaudata, and T. inermis) were also among the most important in terms of catch weight. These animals may more effectively avoid capture by the sampling gear than for instance the hydromedusa and the chaetognaths, and to some extent are underestimated in the catches (Table S2). The mesopelagic fish B. glaciale was also caught regularly in the deep MIK hauls, but in quite low numbers, as they are probably rare, but also capable of avoidance (Kaartvedt et al., 2012).

\section{Weighted Mean Depth (WMD) in Relation to Environmental Parameters}

The sampling from two locations in the Sofia Deep was conducted in $20-80 \%$ sea ice coverage and the midnight sun (24 h of sunlight, Table 1, Figures 3A,B). The northernmost location had an almost three times stronger light difference compared to the southernmost location (25.2 kLUX as compared to $9.2 \mathrm{kLUX})$, but substantially smaller WMD range $(67 \mathrm{~m}$ as compared to $151 \mathrm{~m}$, Table 2, Figures $3 \mathbf{3 A}, \mathbf{B}$ ). This might be due to less light transparency at the northernmost location due to heavier sea ice as well as higher fluorescence levels in the upper $100 \mathrm{~m}$ (Table 1, Figure S2 and Table S3). The median difference between high-light and low-light WMD show that there is no 

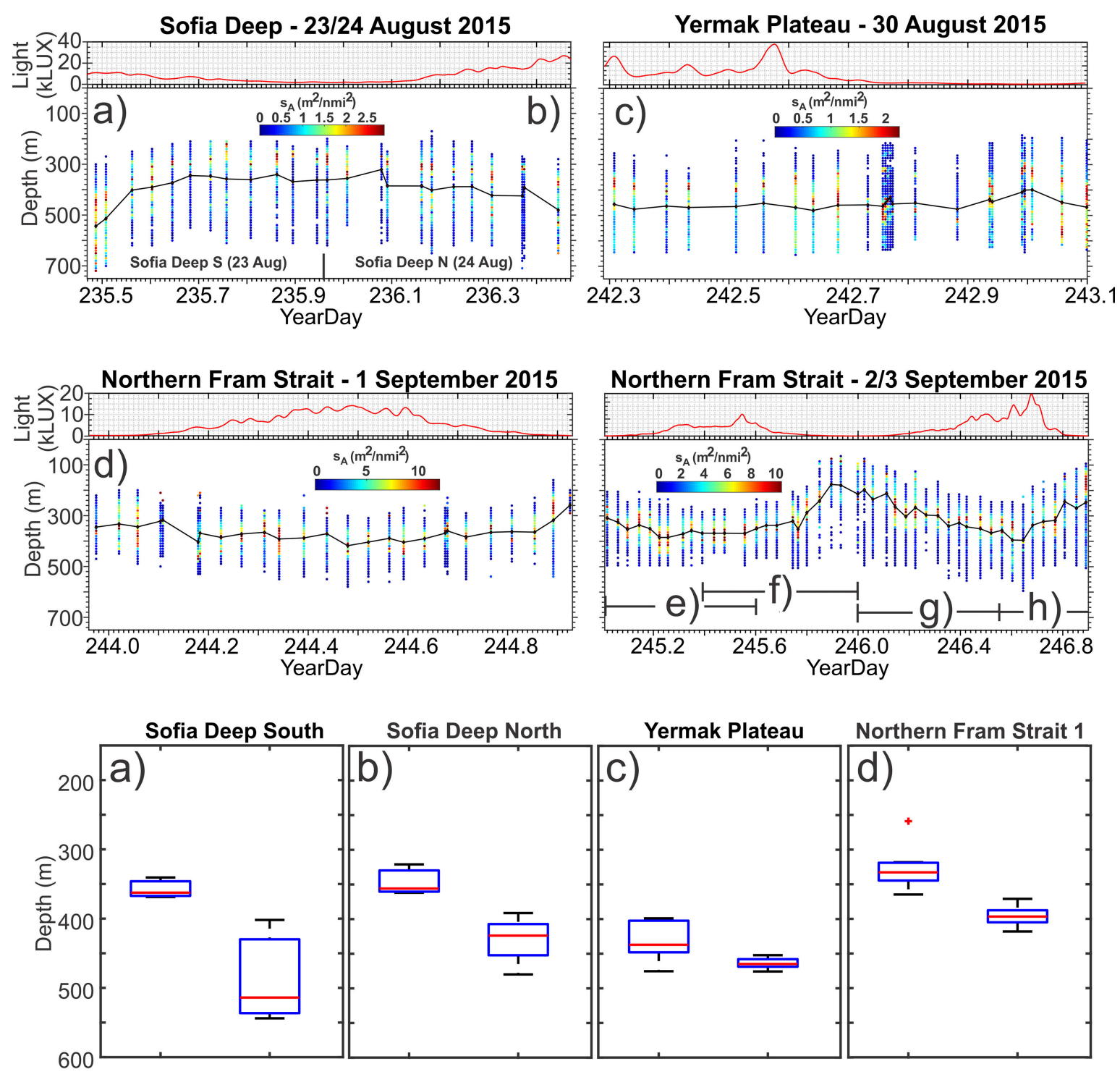

Sofia Deep North

Yermak Plateau

Northern Fram Strait 1

Northern Fram Strait 2 Northern Fram Strait 3 Northern Fram Strait 4 Northern Fram Strait 5

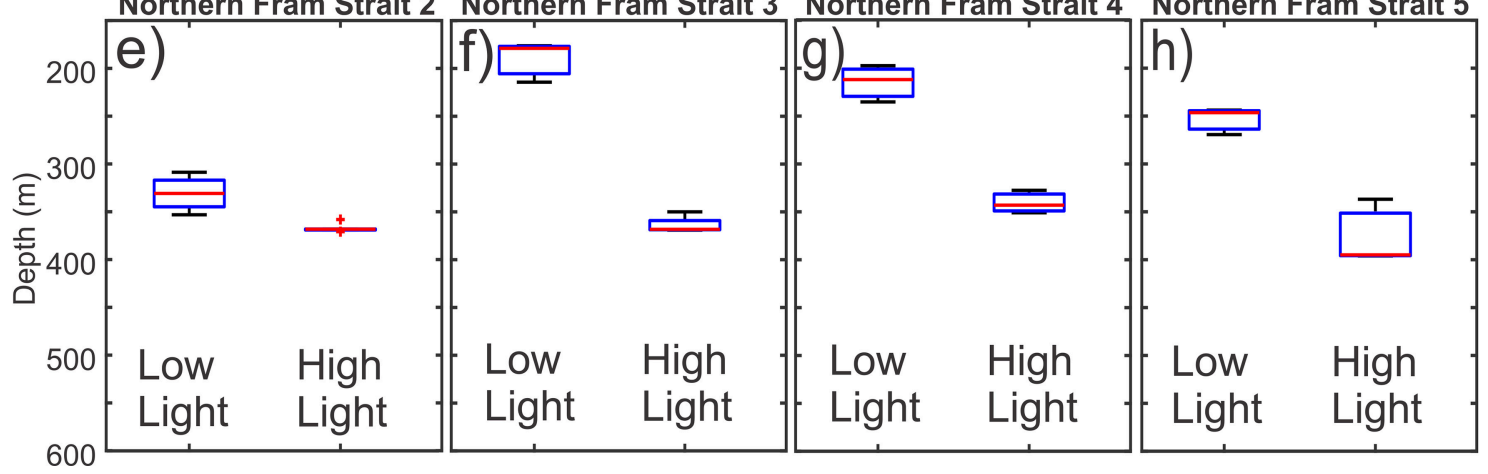

FIGURE 3 | Light levels and vertical distribution of scrutinized acoustic DSL NASC data assessed as originating from backscattering from mesopelagic organisms (two upper panels), and box plots of the depths of the high-light and low-light depths of weighted mean value of scrutinized DSL backscattering at $38 \mathrm{k} 3 \mathrm{~Hz}$ (two lower panels). Panels (a-h) denote the eight locations visited (see text for details). 
TABLE 2 | Weighted mean depth (m) statistics for the four time periods.

\begin{tabular}{|c|c|c|c|c|c|c|c|}
\hline $\begin{array}{l}\text { Light } \\
\text { level }\end{array}$ & $\begin{array}{c}\text { kLUX } \\
\text { difference }\end{array}$ & Min & 25th & Median & 75th & Max & $\begin{array}{c}\text { Median } \\
\text { difference }(m)\end{array}$ \\
\hline \multicolumn{8}{|c|}{ WEIGHTED MEAN DEPTH STATISTICS } \\
\hline \multicolumn{8}{|c|}{ SOFIA DEEP N, 24 AUGUST 2015} \\
\hline Low-light & 25.2 & 321 & 330 & 356 & 360 & 362 & 67 \\
\hline High-light & & 391 & 407 & 424 & 452 & 480 & \\
\hline \multicolumn{8}{|c|}{ SOFIA DEEP S, 23 AUGUST 2015} \\
\hline Low-light & 9.2 & 341 & 346 & 362 & 367 & 369 & 151 \\
\hline High-light & & 402 & 430 & 514 & 536 & 544 & \\
\hline \multicolumn{8}{|c|}{ YERMAK PLATEAU, 30 AUGUST 2015} \\
\hline Low-light & 42.5 & 399 & 402 & 437 & 448 & 475 & 27 \\
\hline High-light & & 452 & 458 & 465 & 468 & 476 & \\
\hline \multicolumn{8}{|c|}{ NORTHERN FRAM STRAIT 1, 1 SEPTEMBER 2015} \\
\hline Low-light & 14.1 & 318 & 319 & 333 & 34445 & 365 & 63 \\
\hline High-light & & 371 & 388 & 397 & 40494 & 418 & \\
\hline \multicolumn{8}{|c|}{ NORTHERN FRAM STRAIT 2, 2 SEPTEMBER 2015} \\
\hline Low-light & 12.8 & 309 & 317 & 331 & 34482 & 353 & 37 \\
\hline High-light & & 368 & 368 & 368 & 36909 & 369 & \\
\hline \multicolumn{8}{|c|}{ NORTHERN FRAM STRAIT 3, 2 SEPTEMBER 2015} \\
\hline Low-light & 12.8 & 176 & 177 & 179 & 20551 & 214 & 189 \\
\hline High-light & & 350 & 359 & 368 & 36866 & 369 & \\
\hline \multicolumn{8}{|c|}{ NORTHERN FRAM STRAIT 4, 3 SEPTEMBER 2015} \\
\hline Low-light & 12.9 & 197 & 201 & 212 & 22940 & 235 & 131 \\
\hline High-light & & 328 & 331 & 343 & 34901 & 351 & \\
\hline \multicolumn{8}{|c|}{ NORTHERN FRAM STRAIT 5, 3 SEPTEMBER 2015} \\
\hline Low-light & 24.7 & 244 & 244 & 246 & 26364 & 269 & 148 \\
\hline High-light & & 337 & 351 & 395 & 39579 & 396 & \\
\hline
\end{tabular}

overlap in the median boxplot values and the low-light and high-light WMDs (Figures 3A,B). Also interesting is that the difference in WMD range is due to differences in the maximum depth; the WMD both locations is at about $350-360 \mathrm{~m}$ depth during low light, but with larger differences during high-light (Table 2, Figure 4).

The sampling from the Yermak Plateau were conducted at the ice edge during the midnight sun ( $24 \mathrm{~h}$ of sunlight, Table 1, Figure 3C). This location had the highest light difference among the samples (42.5 kLUX), but the lowest WMD range $(27 \mathrm{~m}$, Table 2). The fluorescence and turbidity in the upper $100 \mathrm{~m}$ were somewhat average indicating that the light absorption should be about the same as at the other localities (Table S3). It is also worth noting that the light conditions were quite variable (Figure 3C) and the most intense light, causing the high light difference, only occurred for a short period.

In northern Fram Strait, five localities were sampled (Table 1, Figures 3D-H). All of them were sampled in open water and after the midnight sun had set ( $19 \mathrm{~h}$ of sunlight). Four of the localities showed light differences of 12-14 kLUX, while one showed a higher light difference (24.7 kLUX) which was comparable to the northernmost locality in the Sofia Deep. The range of the WMD varied substantially, between 37 and $189 \mathrm{~m}$, and with no obvious link either toward light level difference or fluorescence or turbidity (Table 2 and Table S3). However, there were clear differences in vertical migration when comparing the localities across the longitudinal gradient (Figure 4). While the localities in the western part showed WMD spanning a range of 37-64 m, the localities in the eastern part showed WMD over the 131-189 $\mathrm{m}$ depth range.

Compared to the localities further north, the DSL in the northern Fram Strait occurred shallower, although it clearly did not reach the surface layers (Table 2, Figure 4). In contrast to the Sofia Deep localities, all localities in northern Fram Strait showed WMD approaching approximately the same lower depth level at high light (343-397 m), while the upper levels during low light were more variable.

The median difference between high-light and low-light WMD calculated from the acoustic data showed that at all locations except for the Yermak Plateau there was no overlap in the median boxplot values and the low-light and high-light WMDs (Figure 3). A paired $t$-test of the differences between lowlight and high-light depths for the eight comparisons showed the high-light depths were significantly deeper than the lowlight depths $(p<0.001)$. There was, however, no significant statistical relationship between the difference in incident light and the difference in WMD during low-light and high-light periods (Table 2, Figure 4).

Mean hydrographic parameters across the layers where diel vertical migration was taking place show that the variation in WMD occurred in depth layers with mean temperatures ranging from 1.21 to $3.75^{\circ} \mathrm{C}$, with salinities above 34.9 and densities above $27.7 \mathrm{~kg} \mathrm{~m}^{-3}$ (Table 1, Figure 4). All these values, including all minimum values (Table S3), are within the definition of Atlantic Water $\left(0^{\circ} \mathrm{C}<\mathrm{T}, 34.9<\mathrm{S}\right.$; derived from Rudels et al., 2005). Thus, the observed diel vertical migration seems to be confined to the middle or lower part of the Atlantic Water despite no obvious environmental constraints or gradients (in water mass characteristics, vertical layering, or oxygen) regulating the vertical extent of the migration (Figure 4).

\section{DISCUSSION}

The DSL is a ubiquitous feature of most of the world's oceans and visible on nearly all ship's echo sounders (Tont, 1976; Cade and Benoit-Bird, 2014; Irigoien et al., 2014). Mesopelagic fishes are the main contributors to the scatterers that inhabit the twilight zone between 200 and $1,000 \mathrm{~m}$ depth. In the oceanic regions of North Atlantic the DSL is a well-known feature (Melle et al., 1993; Magnússon, 1996; Torgersen et al., 1997; Sigurðsson et al., 2002; Pepin, 2013; St. John et al., 2016). Several of these investigators show that the horizontal and vertical extension as well as acoustic magnitude or density of this mesopelagic layer can vary considerably depending on region, season, water mass characteristics, and time of day. Light conditions at the surface and ocean transparency that modifies light penetration into deep water, are factors that has been documented to be of crucial importance for vertical distribution of mesopelagic scatterers and diel vertical migration behavior (Dickson, 1972 and references therein; Norheim et al., 2016). 


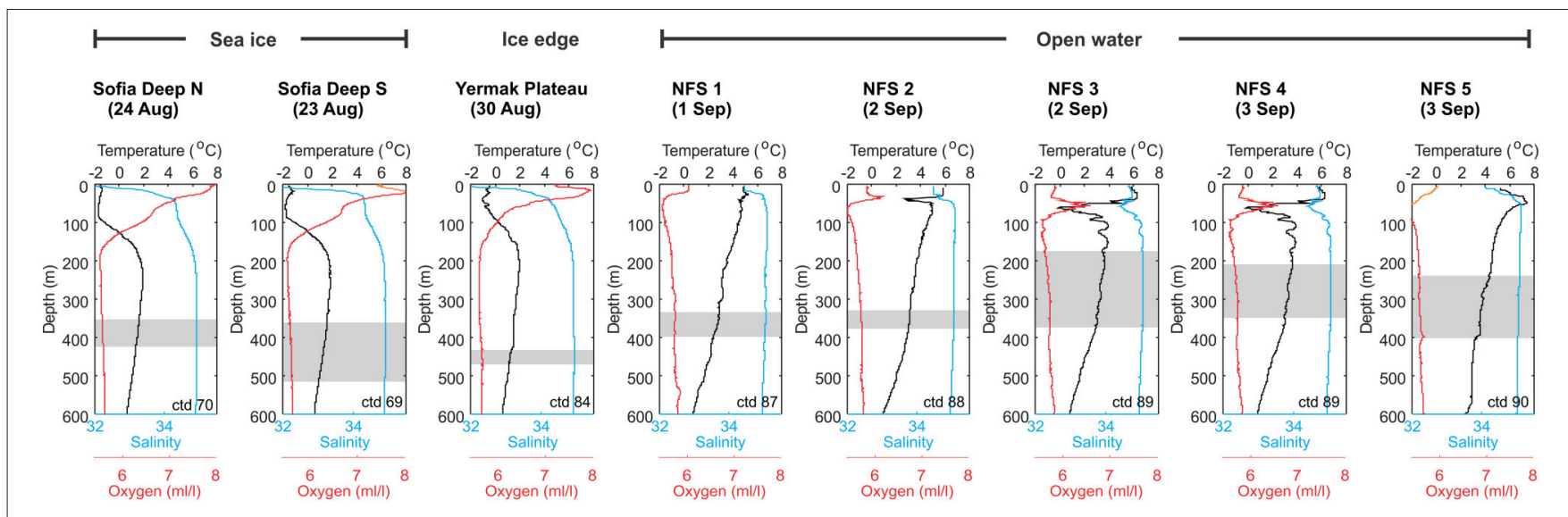

FIGURE 4 | Vertical profiles of temperatures (black line), salinity (green line), and oxygen content (red line) at the eight locations where diel vertical migration of the DSL was studied. The extent of the WMD is shaded on each figure.

\section{Arctic Deep-Scattering Layers Past and Present}

Contrasting the situation at lower latitudes, the presence of DSLs in the Arctic is not well documented. Hunkins (1965) described a scattering layer observed from Fletcher's Ice Island (T-3), a drifting research station in the central Arctic Ocean. It was present during the summer months at depths 50-200 m, and no diel pattern could be seen. During winter and spring the layer disappeared. Hansen and Dunbar (1971) analyzed data from the same ice island observatory, but in addition to the $12 \mathrm{kHz}$ echo sounder operated by Hunkins they used an echo sounder operated at $100 \mathrm{kHz}$ and could locate an additional SSL at shallow depths. By sampling in the relevant depths, they concluded that this layer consisted of the pteropod Spiratella (now Limacina) helicina. They were not able to catch any organisms from the deeper layer detected on both frequencies, but speculated that this layer consisted of the arctic gadoid A. glacialis, a species they occasionally caught from surface waters through holes in the ice. The DSLs detected under the multi-year ice in the Central Arctic Ocean revealed two important features that distinguish this layer from that observed in the non-polar oceans. The arctic layer occurred at moderately shallow depths and exhibited annual rather than diel cycles.

During the present study between latitudes $79^{\circ} 40^{\prime}$ and $82^{\circ} 10^{\prime}$, where the bottom depth was mostly $>1,000 \mathrm{~m}$ and the sea surface was partly ice covered, a DSL having a low backscattering was present and was populated with various fish and zooplankton species. The DSL was always present from 210 to $510 \mathrm{~m}$ depth, but the upper and lower limits of the DSL varied geographically. The DSL performed a diel vertical migration between the high-light and low-light periods of day when the sun was above the horizon $24 \mathrm{~h}$ and when it started to set at night. The observed differences in WMD of the DSL between high-light and low-light conditions were rather small among the eight locations where data were analyzed; from 27 to $189 \mathrm{~m}$, which is less than in most areas where diel vertical migration has been studied. The reason for the rather restricted range with respect to diel vertical migration could reflect the limited difference between light conditions day and night compared to lower latitudes.

Our results showed that diel vertical migration occurred in all eight localities sampled in this study; in open water after the midnight sun had set in northern Fram Strait, at the ice edge at the Yermak Plateau during the midnight-sun period, and in sea ice covered $(20-80 \%$ sea ice concentration) waters in the Sofia Deep also during the midnight-sun period (Tables 1, 2, Figure 3). The diel vertical migration showed, however, large variations among the localities. Some of these differences seemed to be linked to differences in light penetration due to sea ice and high fluorescence levels in the upper water layers, while other were not. The results also showed clear differences in vertical migration when comparing the localities across a longitudinal gradient in the northern Fram Strait; localities in the eastern part spanned a substantial larger WMD range than the localities in the western part (Figures 3, 4). The DSL in the eastern part, which is closer to the shelf break, was dominated by larger fishes (including cod) as compared to further west (Knutsen et al., 2017, Table S1). Larger fishes also migrate on daily cycles, and e.g., cod migrations can span ranges up to $250 \mathrm{~m}$ (e.g., Godø and Michalsen, 2000; Michalsen et al., 2013). Thus, it is possible or even likely that the differences in diel migration across the northern Fram Strait section is linked to differences in species composition.

\section{Relationships between Scattering Layers, Environmental Constraints, and Advection}

Earlier studies have shown that, in addition to light, temperature and oxygen are important factors regulating diel vertical migration (e.g., Klevjer et al., 2016). Our results indicated that although there are no obvious environmental constraints (in water mass characteristics, vertical layering, or oxygen) regulating the vertical extent of the migration (Figure 4), the WMD seems to be confined to the middle or lower part of the Atlantic Water. In the eastern part of the Norwegian Sea, a DSL has been observed in association with the Atlantic Water 
flowing north along the Norwegian coast (Melle et al., 1993; Torgersen et al., 1997; Dale et al., 1999; Knutsen and Serigstad, 2001; Siegelman-Charbit and Planque, 2016). It seems likely that the migrating animals we observed are organisms that passively follow the West Spitsbergen Current transporting Atlantic Water northwards toward the Arctic Ocean.

When flowing northwards through Fram Strait and toward the region north of Svalbard the Atlantic Water cools and freshens, particularly in the upper $600 \mathrm{~m}$, due to heat loss to the atmosphere, ice melt and by intrusions of cold, brine enriched water sinking from the Svalbard shelf (e.g., Rudels et al., 2005). When the layer increases in density and deepens when going northwards the organisms follow. This could explain the deeper location of the DSL on the Yermak Plateau and Sofia Deep compared to the northern Fram Strait (Figures 3, 4). We hypothesize that the organisms inhabiting the DSL in the study area are passively advected with the Atlantic Water. Using an advection velocity of $0.05-0.1 \mathrm{~m} \mathrm{~s}^{-1}$, the advection time from e.g., $68^{\circ} \mathrm{N}$ in the eastern part of the Norwegian Sea $(\sim 1,500 \mathrm{~km}$ upstream) is $6-12$ months, and if located in the core of the swift West Spitsbergen Current (velocities near $0.2-0.3 \mathrm{~m} \mathrm{~s}^{-1}$ ) it is only $2-3$ months. The DSL deepens northwards, but the organisms maintain their migration behavior resulting in diel vertical migration across a deep ( $\sim 350$ to $500 \mathrm{~m}$ ) layer north of Svalbard, completely disconnected from the surface layer. Whether the diel vertical migration still serves the purpose of seeking favorable feeding conditions under low predation risk, giving these organisms an advantage over non-migrating organisms, or is just a remnant of this ecological adaptation from their more southern origin, is unknown.

Current knowledge suggests that there exists a north-south gradient both with respect to species composition and abundance of organism that constitute the DSL in the eastern NorthAtlantic. The samples obtained with the Åkra trawl, the Macroplankton trawl, and the MIK net contained mesopelagic fishes species but in very small quantities (Tables S1, S2). The invertebrate portion of the DSL was not very different from that reported further south (Melle et al., 1993; Torgersen et al., 1997; Knutsen and Serigstad, 2001), but the vertical extension of the DSL, the integrated backscatter (NASC), a proxy for biomass contained in the DSL, and the extent of vertical migration was smaller in these northern areas compared to what has been reported from more southern parts of the Norwegian Sea (Melle et al., 1993; Torgersen et al., 1997; Knutsen and Serigstad, 2001) and from the western NorthAtlantic (Magnússon, 1996; Sigurðsson et al., 2002; Anderson et al., 2005).

\section{Diel Vertical Migration Patterns}

Diel vertical migration among organisms has been described previously under Arctic summer conditions. For instance, Rabindranath et al. (2011) described diel vertical migration in the upper $50 \mathrm{~m}$ of copepods (three Calanus species and Metridia longa) at six locations to the north and northwest of Svalbard (latitudes $79-81^{\circ} \mathrm{N}$ ) during August 2008. These stations were found in fjords and over the shelf and were too shallow to have a DSL. A diel light cycle was clearly observed despite midnight-sun conditions, and while net-determined depthstratified abundance did not reveal any significant difference between day and night, acoustic data with $25 \mathrm{~m}$ vertical resolution resulted in significant differences between day and night backscatter strength vs. depth across all stations. In contrast, Blachowiak-Samolyk et al. (2006) postulated, based on their studies in the Barents Sea marginal ice zone (latitudes $76-77^{\circ} \mathrm{N}$ ) and a comprehensive literature survey, that common zooplankton taxa do not perform diel vertical migration under the midnight sun. Neither study area was deep enough to have a DSL, and consequently cannot be directly compared to the present study.

Siegelman-Charbit and Planque (2016), using data from four acoustic surveys in the central and northern Norwegian Sea, concluded that the DSL observed at all four surveys performed daily migration patterns similar to those reported in other regions. They did not analyze any biological samples from those surveys and the composition of the DSL in their study area is therefore not known. However, they report on average $\mathrm{s}_{\mathrm{A}^{-}}$ values from the mesopelagic layer from the four surveys (three in August and one in May), which ranged from 81 to 215, decreasing from south to north. Their northernmost survey was conducted in a region just south of where our southernmost observations were made. Our results fit well with the results from these more southerly regions of the Norwegian Sea that show acoustic energy from the mesopelagic layer decreases with increasing latitude. Knutsen et al. (2017) also observed this pattern of DSL backscattering intensity decreasing from the south-eastern Norwegian Sea region to Arctic waters north of Svalbard. This pattern agrees with «photoperiod constraint hypothesis $\gg$ (Kaartvedt, 2008).

There are apparently quite large differences east-west in the northern Atlantic Ocean with regard to the composition of the mesopelagic community. In the Irminger Sea Sigurðsson et al. (2002) report on a very diverse mesopelagic community that included eight species of myctophids. In addition, the mesopelagic layer there extended to depths of more than $800 \mathrm{~m}$ with a total vertical extension of up to $450 \mathrm{~m}$, which is substantial compared to the eastern Norwegian Sea (cf. Melle et al., 1993; Torgersen et al., 1997). In the eastern Norwegian Sea, the DSL also consisted of far fewer species of which the most important were krill ( $M$. norvegica), mesopelagic fish (Maurolicus muelleri, B. glaciale), shrimps (S. arcticus, Pasiphaea multidenta, Hymenodora glaciale), and the Scyphozoan (Periphylla periphylla; Melle et al., 1993; Torgersen et al., 1997; Knutsen and Serigstad, 2001), but also included blue whiting (Micromesistius poutassou). An important difference in species composition between the earlier studies in the southeastern Norwegian Sea is the nearly complete absence of blue whiting and Mueller's pearlside (M. muelleri) found during this study in the Svalbard region and confirmed by Knutsen et al. (2017).

Diel vertical migration in shallow or deep marine ecosystems pertain to the migration behavior of a range of organisms, having different life history strategies, and for which internal state and external factors can also act to modify migration 
patterns (Kaartvedt, 2010; Sogawa et al., 2016). Moreover, diel vertical migration is often explained as a trade-off between feeding and predation risk near the surface (Mauchline, 1980; Gibbons, 1993; De Robertis, 2002; Pearre, 2003; Kaartvedt, 2010). Many organisms that constitute DSLs, from krill and mesopelagic shrimps (Kaartvedt et al., 1988; Giske et al., 1990), to mesopelagic fishes of various types (Melle et al., 1993; Torgersen et al., 1997; Knutsen and Serigstad, 2001) display diel vertical migration, and quite certainly these migrations are linked to the ambient light environment and possibly light is also the proximate cue for the onset of vertical migration. This has been demonstrated on several occasions (see Norheim et al., 2016 and references therein), who observed that variation in migration amplitude is consistent with a behavior whereby the organisms constituting the DSL keep their ambient light intensities within a particular range. Thus, the smaller amplitude of DVM at higher latitudes observed in this study is likely due to the limited day and night difference in light conditions compared to low latitudes.

\section{Relation to Larger Predators}

In the high Arctic as during the present study with a near 24-h light regime, the abundance of larger pelagic fish predators in the surface waters were limited, although frequent sightings of baleen whales, possibly feeding on schooling krill and amphipods, and dense registrations of copepods (see Knutsen et al., 2017), were recorded. It is however, difficult to assess the predation risk for migrating mesopelagics here, compared to regions further south. The ambient light regime on the other hand, is extreme during the Arctic summer months and very different compared to lower latitudes, with sharp day-night differences in light irradiance. Despite a 24-h light regime, with the sun mostly above the horizon during the current investigations, diel vertical migration was still evident. However, the organisms constituting the DSL did not seem to migrate all the way to the surface layers, rather their migration seems arrested at intermediate depths (cf. Figure 4, Table 2). This could indicate that the organisms in the DSL, for some reason do not reach the potentially better foraging areas closer to the surface. The depth at which they seem arrested could coincide with an underwater light level that the animals do not transcend (cf. Norheim et al., 2016) and could explain the limited diel vertical migrations, but we have unfortunately no in situ light data that can support such an interpretation. Also, since no mesopelagic fishes were caught in the shallow hauls in the upper $0-60 \mathrm{~m}$ irrespective of time of day, it seems a fair interpretation that mesopelagic migrants avoid the near surface layer in this region. Thus, the results of the present study seem to support the proposed "photoperiod constraint hypothesis" (Kaartvedt, 2008), suggesting that high night light intensities in summer at high latitudes limit options for safe foraging in upper layers at night.

\section{CONCLUSIONS}

While the presence of scattering layers has been documented further north, in an area permanently covered with ice, those scattering layers where found at shallower depths (20-200 m, Hunkins, 1965; Hansen and Dunbar, 1971) and might not qualify for the term DSL. Here, we demonstrate that a DSL at depths of $210-510 \mathrm{~m}$ exists at the Atlantic gateway to the Arctic Ocean, also extending into ice-covered waters. We also demonstrate that diel vertical migration is a feature of this DSL with WMDs of the DSL varying between 27 and $189 \mathrm{~m}$ even when the sun is above the horizon for $24 \mathrm{~h}$ Thus, our null-hypothesis: during continuous daylight there is no evidence of diel vertical migration, is rejected. Further, our results corroborate earlier findings that there is a gradual decrease in species richness, vertical extension, biomass, and amount of diel vertical migration with increasing latitude in the Northeast Atlantic-Norwegian Sea-Fram Strait (Torgersen et al., 1997; Norheim et al., 2016; Siegelman-Charbit and Planque, 2016; Knutsen et al., 2017). The findings agree with the "photoperiod constraint hypothesis" (Kaartvedt, 2008), but given the data currently available, it is not possible to definitively ascribe the low biomass and the modest diel vertical migration of the DSL to the light regime. Our findings show that even in this extreme environment, ice-covered during large parts of the year and with an Arctic light regime, the environmental and biological conditions allow for the existence of a DSL. How consistent this feature is over time and area in terms of biomass and species composition remains to be revealed.

DSL dynamics have been shown to be highly variable, and further studies need to be undertaken to make a comprehensive investigation on differences in species composition relative to environmental parameters. This should include either long periods of sampling at a single site including observations of prey-predator occurrence as well as physical characteristics of the water column, or repeated studies over a number of years and light conditions. Traditional sampling techniques could be applied, but also complementary novel approaches like acoustic and video probe systems (Godø et al., 2014), towed underwater multisensor vehicles with acoustic sensors (cf. Knutsen et al., 2013), and new trawl technology (DeepVison, Rosen et al., 2013; Underwood et al., 2014). These systems can all be operated close to or within the DSL and could increase our knowledge of the organism constituting the DSL, and how the composition and abundance of these vary over time and regionally within the Arctic Ocean. Also, to investigate in detail what species were performing vertical migrations, depthstratified biological sampling as well as continuous biological sampling through a $24-\mathrm{h}$ cycle should be conducted. The deep-water ecosystem of the Arctic is currently one of the greatest unknowns in our understanding of the region and particularly how it could respond to ongoing changes in the epipelagial, affected by increased warming and a reduced sea-ice cover.

\section{AUTHOR CONTRIBUTIONS}

All authors listed, have made substantial, direct and intellectual contribution to the work, and approved it for publication. 


\section{ACKNOWLEDGMENTS}

We gratefully acknowledge the assistance provided by the Captain and Crew of the R/V Helmer Hanssen. Dr. Egil Ona is thanked for assistance with the analysis of the acoustic data. The Research Council of Norway is thanked for the financial support through the projects "The Arctic Ocean Ecosystem" - (SI_ARCTIC, RCN 228896), the "Effects of climate change on the Calanus complex"-(ECCO, RCN 200508), "Harvesting marine cold water plankton species-abundance estimation and stock assessment"-(Harvest II, RCN 203871). The work is a contribution to the Barents and Norwegian Sea Ecosystem Program at IMR.

\section{REFERENCES}

Anderson, C. I. H., Brierley, A. S., and Armstrong, F. (2005). Spatio-temporal variability in the distribution of epi- and meso-pelagic acoustic backscatter in the Irminger Sea, North Atlantic, with implications for predation on Calanus finmarchicus. Marine Biol. 146, 1177-1188. doi: 10.1007/s00227-004-1510-8

Beitsch, A., Kaleschke, L., and Kern, S. (2014). Investigating high-resolution AMSR2 sea ice concentrations during the February 2013 fracture event in the beaufort sea. Remote Sens. 6, 3841-3856. doi: 10.3390/rs6053841

Blachowiak-Samolyk, K., Kwasniewski, S., Richardson, K., Dmoch, K., Hansen, E., Hop, H., Falk-Petersen, S., et al. (2006). Arctic zooplankton do not perform diel vertical migration (DVM) during periods of midnight sun. Mar. Ecol. Prog. Ser. 308, 101-116. doi: 10.3354/meps308101

Brierley, A. S. (2014). Diel vertical migration. Curr. Biol. 24, R1074-R1076. doi: $10.1016 /$ j.cub.2014.08.054

Cade, D. E., and Benoit-Bird, K. J. (2014). An automatic and quantitative approach to the detection and tracking of acoustic scattering layers. Limnol. Oceanogr. Methods 12, 742-756. doi: 10.4319/lom.2014.12.742

Clarke, G. L. (1971). "Light conditions in the sea in relation to the diurnal vertical migration of animals," in Proceedings of the International Symposium on Biological Sound Scattering in the Ocean, ed G. B. Farquhar (Washington, DC: Maury Center for Ocean Science), 41-50. Report No. MC-005.

Cohen, J. H., Berge, J., Moline, M. A., Sørensen, A. J., Last, K., FalkPetersen, S., et al (2015). Is ambient light during the high arctic polar night sufficient to act as a visual cue for zooplankton? PLoS ONE 10:e0126247. doi: 10.1371/journal.pone.0126247

Cronin, H. A., Cohen, J. H., Berge, J., Johnsen, G., and Moline, M. A. (2016). Bioluminescence as an ecological factor during high Arctic polar night. Sci. Rep. 6:36374. doi: 10.1038/srep36374

Dale, T., Bagøien, E., Melle, W., and Kaartvedt, S. (1999). Can predator avoidance explain varying overwintering depth of Calanus in different oceanic water masses? Mar. Ecol. Prog. Ser. 179, 113-121. doi: 10.3354/meps179113

De Robertis, A. (2002). Size-dependent visual predation risk and the timing of vertical migration: an optimization model. Limnol. Oceanogr. 47, 925-933. doi: $10.4319 /$ lo.2002.47.4.0925

Dickson, R. R. (1972). On the relationship between ocean transparency and the depth of sonic scattering layers in the North Atlantic. J. Conseil Int. Pour l'Explor. Mer. 34, 416-422. doi: 10.1093/icesjms/34.3.416

Eyring, C. F., Christensen, R. J., and Raitt, R. W. (1948). Reverberation in the sea. J. Acoust. Soc. Am. 20, 462-475. doi: 10.1121/1.1906399

Forward, R. B. (1976). "Light and diurnal vertical migration: photobehavior and photophysiology of plankton," in Photochemical and Photobiological Reviews, Vol. 1, ed K. C. Smith (Boston, MA: Springer), 157-209.

Frank, T. M., and Widder, E. A. (1999). Comparative study of the spectral sensitivities of mesopelagic crustaceans. J. Comp. Physiol. A 185, 255-265. doi: $10.1007 /$ s003590050385

Gibbons, M. J. (1993). Vertical migration and feeding of Euphausia lucens at two $72 \mathrm{~h}$ stations in the southern Benguela upwelling region. Mar. Biol. 116:257. doi: $10.1007 / \mathrm{BF} 00350016$

\section{SUPPLEMENTARY MATERIAL}

The Supplementary Material for this article can be found online at: https://www.frontiersin.org/articles/10.3389/fmars. 2017.00332/full\#supplementary-material

Figure S1 | Theoretical daily cycle of solar elevation above/below the horizon at the date and location of the experiments: Sofia Deep N and Sofia Deep S (at $81^{\circ} 45^{\prime} \mathrm{N}$ ) on 24 August and 23 August, Yermak Plateau (at $80^{\circ} 55^{\prime} \mathrm{N}$ ) on 30 August, and in Northern Fram Strait $\left(78^{\circ} 40^{\prime} \mathrm{N}\right)$ on 1, 2, and 3 September 2015.

Figure S2 | Vertical profiles of fluorescence (black line) and turbidity (blue line), both measured with Seapoint sensors on the CTD, in the upper $200 \mathrm{~m}$ at the eight locations where diel vertical migration of the DSL was studied. Note a different fluorescence scale for the profile from Sofia Deep $\mathrm{N}$ compared to the others.

Giske, J., Aksnes, D. L., Baliño, B. M., Kaartvedt, S., Lie, U., Nordeide, J. T., et al. (1990). Vertical distribution and trophic interactions of zooplankton and fish in Masfjorden, Norway. Sarsia 75, 65-81. doi: 10.1080/00364827.1990.10413442

Godø, O. R., Handegard, N. O., Browman, H. I., Macaulay, G. J., Kaartvedt, S., Giske, J., et al. (2014). Marine ecosystem acoustics (MEA): quantifying processes in the sea at the spatio-temporal scales on which they occur. ICES J. Mar. Sci. 71, 2357-2369. doi: 10.1093/icesjms/fsu116

Godø, O. R., and Michalsen, K. (2000). Migratory behaviour of north-east Arctic cod, studied by use of data storage tags. Fish. Res. 48, 127-140. doi: 10.1016/S0165-7836(00)00177-6

Hansen, W. J., and Dunbar, M. J. (1971). “Biological causes of scattering layers in the Arctic Ocean," in Proceedings of the International Symposium on Biological Sound Scattering in the Ocean, ed G. B. Farquhar (Washington, DC: Maury Center for Ocean Science), 508-526. Report No. MC-005

Hays, G. C. (2003). "A review of the adaptive significance and ecosystem consequences of zooplankton diel vertical migrations," in Migrations and Dispersal of Marine Organisms. Hydrobiologia,Vol. 503, eds M. B. Jones, A. Ingólfsson, E. Ólafsson, G. V. Helgason, K. Gunnarsson, and J. Svavarsson (Netherlands: Springar), 163-170.

Heywood, K. J. (1996). Diel vertical migration of zooplankton in the Northeast Atlantic. J. Plankton Res. 18, 163-184. doi: 10.1093/plankt/18.2.163

Hunkins, K. (1965). The seasonal variation in the sound-scattering layer observed at Fletcher's Ice Island (T3) with a 12 kc/s echo sounder. Deep Sea Res. 12, $879-881$.

ICES (2013). Manual for the Midwater Ring Net sampling during IBTS Q1. Series of ICES Survey Protocols SISP 2-MIK 2. 18. ISBN 978-87-7482-129-8.

ICES (2015). Manual for International Pelagic Surveys (IPS). Series of ICES Survey Protocols SISP 9 - IPS. 1-92.

Ingvaldsen, R. B., Bucklin, A., Chierici, M., Gjøsæter, H., Haug, T., Hosia, A., et al. (2016). Cruise Report SI_ARCTIC/Arctic Ecosystem Survey R/V Helmer Hanssen, 17 August-7 September 2015. Toktrapport/Havforskningsinstituttet/ISSN 1503 6294/Nr. 14-2016. Avaliable online at: http://www.imr.no/filarkiv/2016/12/cruise_report_si_arctic_2015_ final.pdf/nb-no

Irigoien, X., Klevjer, T. A., Røstad, A., Martinez, U., Boyra, G., Acuna, J. L., Bode, A., et al. (2014). Large mesopelagic fishes' biomass and trophic efficiency in the open ocean. Nat. Commun. 5:3271. doi: 10.1038/ncomms4271

Ji, R., Jin, M., and Varpe, Ø. (2013). Sea ice phenology and timing of primary production pulses in the Arctic Ocean. Global Change Biol. 19, 734-741. doi: $10.1111 /$ gcb. 12074

Kaartvedt, S. (2008). Photoperiod may constrain the effect of global warming in arctic marine systems. J. Plankton Res. 30, 1203-1206. doi: 10.1093/plankt/fbn075

Kaartvedt, S. (2010). Diel vertical migration behaviour of the Northern krill (Meganyctiphanes norvegica Sars). Adv. Mar. Biol. 57, 255-275. doi: 10.1016/B978-0-12-381308-4.00009-1

Kaartvedt, S., Aksnes, D. L., and Aadnesen, A. (1988). Winter Distribution of Macroplankton and Micronekton in Masfjorden, Western Norway. Mar. Ecol. Prog. Ser. 45, 45-55. doi: 10.3354/meps045045 
Kaartvedt, S., Knutsen, T., and Holst, J. C. (1998). Schooling of the vertically migrating mesopelagic fish Maurolicus muelleri in light summer nights. Mar. Ecol. Prog. Ser. 170, 287-290. doi: 10.3354/meps170287

Kaartvedt, S., Melle, W., Knutsen, T., and Skjoldal, H. R. (1996). Varying distribution of fish and krill beneath water of varying optical properties. Mar. Ecol. Prog. Ser. 136, 51-58. doi: 10.3354/meps136051

Kaartvedt, S., Staby, A., and Aksnes, K. L. (2012). Efficient trawl avoidance by mesopelagic fishes causes large underestimation of their biomass. Mar. Ecol. Prog. Ser. 456, 1-6. doi: 10.3354/meps09785

Kaleschke, L., and Tian-Kunze, X. (2016). AMSR2 ASI $3.125 \mathrm{~km}$ Sea Ice Concentration Data, V0.1. Institute of Oceanography; University of Hamburg, Germany, digital media. Available online at: ftp://ftp-projects.cen.unihamburg.de/seaice/AMSR2/3.125km/ (accessed August 30, 2015).

Kampa, E. M. (1971). "Photoenvironment and sonic scattering," in Proceedings of the International Symposium on Biological Sound Scattering in the Ocean, ed G. B. Farquhar (Washington, DC: Maury Center for Ocean Science), 51-59. Report No. MC-005.

Klevjer, T. A., Irigoien, X., Røstad, A., Fraile-Nuez, E., Benitez-Barrios, V. M., and Kaartvedt, S. (2016). Large scale patterns in vertical distributrion and behavior of mesopelagic scattering layers. Sci. Rep. 6:19873. doi: 10.1038/srep 19873

Knutsen, T., and Serigstad, B. (2001). Potential Implications on the Pelagic Fish and Zooplankton Community of Artificially Induced Deep-Water Releases of Oil and Gas during DeepSpill_2000 - An Innovative Acoustic Approach, Vol. 14. Fisken og Havet, 1-37. Available online at: http://www.imr.no/filarkiv/2003/08/ biology_report.pdf/nb-no

Knutsen, T., Melle, W., Mjanger, M., Strand, E., Fuglestad, A.-L., Broms, C., et al. (2013). MESSOR - A Towed Underwater Vehicle for Quantifying and Describing the Distribution of Pelagic Organisms and their Physical Environment. Bergen: OCEANS'13 MTS/IEEE. 1-12. ISBN 978-1-4799-0000-8.

Knutsen, T., Wiebe, P. H., Gjøsæter, H., Ingvaldsen, R., and Lien, G. (2017). High latitude epipelagic and mesopelagic scattering layers - a reference for future arctic ecosystem change. Front. Mar. Sci. 4:334. doi: 10.3389/fmars.2017.00334

Korneliussen, R. J., Heggelund, Y., Macaulay, G. J., Patel, D., Johnsen, E., and Eliassen, I. K. (2016). Acoustic identification of marine species using a feature library. Methods Oceanogr. 17, 187-205. doi: 10.1016/j.mio.2016.09.002

Korneliussen, R. J., Ona, E., Eliassen, I., Heggelund, Y., Patel, R., God,ø, O. R., Giertsen, C., et al. (2006). "The large scale survey system - LSSS," in Proceedings of the 29th Scandinavian Symposium on Physical Acoustics (Ustaoset).

Kowalczuk, P., Meler, J., Kauko, H., Pavlov, A. K., Zablocka, M., Peeken, I., et al. (2017). Bio-optical properties of Arctic drift ice and surface waters north of Svalbard from winter to spring. J. Geophys. Res. Oceans 122, 4634-4660. doi: 10.1002/2016JC012589

Kutschale, H. (1969). Arctic hydroacoustics. Arctic 22, 246-264. doi: $10.14430 / \operatorname{arctic} 3218$

Lampert, W. (1989). The adaptive significance of diel vertical migration of zooplankton. Funct. Ecol. 3, 21-27. doi: 10.2307/2389671

Last, K. S., Hobbs, L., Berge, J., Brierley, A. S., and Cottier, F. (2016). Moonlight drives ocean-scale mass vertical migration of zooplankton during the Arctic Winter. Curr. Biol. 26, 244-251. doi: 10.1016/j.cub.2015.11.038

Lund-Hansen, L. C., Markager, S., Hancke, K., Stratmann, T., Rysgaard, S., Ramløv, H., et al. (2015). Effects of sea-ice light attenuation and CDOM absorption in the water below the Eurasian sector of central Arctic Ocean $\left(>88^{\circ} \mathrm{N}\right)$. Polar Res. 34:23978. doi: 10.3402/polar.v34.23978

MacLennan, D. N., Fernandes, P. G., and Dalen, J. (2002). A consistent approach to definitions and symbols in fisheries acoustics. ICES J. Mar. Sci. 59, 365-369. doi: 10.1006/jmsc.2001.1158

Magnússon, J. (1996). The deep scattering layers in the Irminger sea. J. Fish Biol. 49, 182-191. doi: 10.1111/j.1095-8649.1996.tb06075.x

Mauchline, J. (1980). The biology of mysids. Adv. Mar. Biol. 18, 1-369.

Melle, W., Abrahamsen, M., Valdemarsen, J. W., Ellertsen, B., and Knutsen, T. (2006). "Design and performance of a new macro-plankton trawl in combination with a multiple cod-end system," in SCOR Working Group 115, Mini Symposium on Standards for the Survey and Analysis of Plankton (Plymouth) (Accessed May 19-20, 2006).

Melle, W., Kaartvedt, S., Knutsen, T., Dalpadado, P., and Skjoldal, H. R. (1993). "Acoustic visualisation of large scale macroplankton and micronecton distributions across the Norwegian shelf and slope of the Norwegian Sea," in
ICES Council Meetings 1993/L:44:1-25. Avaliable online at: http://ices.dk/sites/ pub/CM\%20Doccuments/1993/L/1993_L44.pdf

Michalsen, K., Dalpadado, P., Eriksen, E., Gjøsæter, H., Ingvaldsen, R., Johannesen, E., et al. (2013). Marine living resources of the Barents Sea - ecosystem understanding and monitoring in a climate change perspective. Mar. Biol. Res. 9, 932-947. doi: 10.1080/17451000.2013.775459

Mundy, C. J., Gosselin, J., Ehn, J., Gratton, Y., Rossnagel, A., Barber, D. G., Martin, J., et al. (2009). Contribution of under-ice primary production of an ice-edge upwelling phytoplankton bloom in the Canadian Beaufort sea. Geophys. Res. Lett. 36, L17601. doi: 10.1029/2009GL038837

Munk, P. (1993). Describing the Distribution and Abundance of Small O-Group Cod using Ring-Net Sampling and Echo-Integration. ICES C.M. 1993/G:40, 13. Avaliable online at: http://ices.dk/sites/pub/CM\%20Doccuments/1993/G/ 1993_G40.pdf

Nicolaus, M., Katlein, C., Maslanik, J., and Hendricks, S. (2012). Changes in Arctic sea ice result in increasing light transmittance and absorption. Geophys. Res. Lett. 39:L24501. doi: 10.1029/2012GL053738

Nicolaus, M., Katlein, C., Maslanik, J., and Hendricks, S. (2013). Correction to "Changes in Arctic sea ice result in increasing light transmittance and absorption." Geophys. Res. Lett. 40, 2699-2700. doi: 10.1002/grl.50523

Norheim, E., Klevjer, T. A., and Aksnes, D. L. (2016). Evidence for light-controlled migration amplitude of a sound scattering layer in the Norwegian Sea. Mar. Ecol. Prog. Ser. 551, 45-52. doi: 10.3354/meps11731

Pearre, S. Jr. (2003). Eat and run? The hunger/satiation hypothesis in vertical migration: history, evidence and consequences. Biol. Rev. 78, 1-79. doi: $10.1017 /$ S146479310200595X

Pepin, P. (2013). Distribution and feeding of Benthosema glaciale in the western Labrador Sea: fish-zooplankton interaction and the consequence to calanoid copepod populations. Deep Sea Res. I 75, 119-134. doi: 10.1016/j.dsr.2013.01.012

Plueddemann, A. J., and Pinkel, R. (1989). Characterization of the patterns of diel migration using a Doppler sonar. Deep Sea Res. 36, 509-530. doi: 10.1016/0198-0149(89)90003-4

Rabindranath, A., Daase, M., Falk-Petersen, S., Wold, A., Wallace, M. I., Berge, J., et al. (2011). Seasonal and diel vertical migration of zooplankton in the High Arctic during the autumn midnight sun of 2008. Mar. Biodivers. 41, 365-382. doi: 10.1007/s12526-010-0067-7

Roe, H. S. (1983). Vertical distributions of euphausiids and fish in relation to light intensity in the northeastern Atlantic. Mar. Biol. 77, 287-298. doi: 10.1007/BF00395818

Roe, H. S. J., Angel, M. V., Badcock, J., Domanski, P., James, P. T., Plugh, P. R., et al. (1984). The diel migrations and distributions within a mesopelagic community in the North East Atlantic. Prog. Oceanogr. 13, 245-511. doi: 10.1016/0079-6611(84)90010-7

Rosen, S., Jörgensen, T., Hammersland-White, D., and Holst, J. C. (2013). Deepvision: a stereo camera system provides highly accurate counts and lengths of fish passing inside a trawl. Can. J. Fish. Aquat. Sci. 70, 1456-1467. doi: 10.1139/cjfas-2013-0124

Rudels, B., Björk, G., Nilsson, J., Winsor, P., Lake, I., and Nohr, C. (2005). The interaction between waters from the Arctic Ocean and the Nordic Seas north of Fram Strait and along the East Greenland Current: results from the Arctic Ocean-02 Oden expedition. J. Mar. Syst. 55, 1-30. doi: 10.1016/j.jmarsys.2004.06.008

Siegelman-Charbit, L., and Planque, B. (2016). Abundant mesopelagic fauna at oceanic high latitudes. Mar. Ecol. Prog. Ser. 546, 277-282. doi: 10.3354/meps11661

Sigurðsson, T. H., Jónsson, G., and Pálsson, J. (2002). "Deep scattering layer over Reykjanes Ridge and in the Irminger Sea," in ICES CM 2002/M:09 1-22 (Copenhagen).

Sogawa, S., Sugisaki, H., Saito, H., Okazaki, Y., Ono, T., Shimode, S., et al. (2016). Seasonal and regional change in vertical distribution and diel vertical migration of four euphausiid species (Euphausia pacifica, Thysanoessa inspinata, T.longipes, and Tessarabrachion oculatum) in the northwestern Pacific. Deep Sea Res. I 109, 1-9. doi: 10.1016/j.dsr.2015.12.010

St. John, M. A., Borja, A., Chust, G., Heath, M., Grigorov, I., Mariani, P., et al. (2016). A dark hole in our understanding of marine ecosystems and their services: perspectives from the mesopelagic community. Front. Mar. Sci. 3:31. doi: $10.3389 /$ fmars.2016.00031 
Tont, S. A. (1976). Deep scattering layers: patterns in the Pacific. Calif. Coop. Ocean. Fish. Invest. Rep. 18, 112-117.

Torgersen, T., Kaartvedt, S., Melle, W., and Knutsen, T. (1997). Large scale distribution of acoustic scattering layers at the Norwegian continental shelf and the eastern Norwegian Sea. Sarsia 82, 87-96. doi: 10.1080/00364827.1997.10413642

Underwood, M. J., Rosen, S., Engås, A., and Eriksen, E. (2014). Deep vision: an intrawl stereo camera makes a step forward in monitoring the pelagic community. PLoS ONE 9:e112304. doi: 10.1371/journal.pone.0112304

Valdemarsen, J. W., and Misund, O. A. (1995). "Trawl designs and techniques used by Norwegian research vessels to sample fish in the pelagic zone," in Precision and Relevance of Pre-recruit Studies for Fishery Management Related to Fish Stocks in the Barents Sea and Adjacent Waters, Proceedings of the Sixth IMR-PINRO Symposium" ed A. Hylen (Bergen: Bergen), 129-144.

Varpe, $\varnothing$., Daase, M., and Kristiansen, T. (2015). A fish-eye view on the new Arctic lightscape. ICES J. Mar. Sci. 72, 2532-2538. doi: 10.1093/icesjms/fsv129

Wassmann, P. (1998). Retention versus export food chains: processes controlling sinking loss from marine pelagic systems. Hydrobiologia 363, 29-57. doi: 10.1023/A:1003113403096

Wassmann, P., and Reigstad, M. (2011). Future Arctic ocean seasonal ice zones and implications for pelagic-benthic coupling. Oceanography 24, 220-231. doi: 10.5670/oceanog.2011.74
Wenneck, T. d. L., Falkenhaug, T., and Bergstad, O. A. (2008). Strategies, methods, and technologies adopted on the R.V. G.O. Sars MAR-ECO expedition to the Mid-Atlantic Ridge in 2004. Deep Sea Res. I 55, 6-28. doi: 10.1016/j.dsr2.2007.09.017

Wiebe, P. H., Allison, D., Kennedy, M., Moncoiffé, G. (2015). A vocabulary for the configuration of net tows for collecting plankton and micronekton. J. Plankton Res. 37, 21-27. doi: 10.1093/plankt/fbu101

Wiebe, P. H., Copley, N. J., and Boyd, S. H. (1992). Coarse-scale horizontal patchiness and vertical migration in newly formed Gulf Stream warm-core ring 82-H, Deep-Sea Res. 39(Suppl. 1), 247-278. doi: 10.1016/S0198-0149(11)80015-4

Conflict of Interest Statement: The authors declare that the research was conducted in the absence of any commercial or financial relationships that could be construed as a potential conflict of interest.

Copyright (c) 2017 Gjøsater, Wiebe, Knutsen and Ingvaldsen. This is an open-access article distributed under the terms of the Creative Commons Attribution License (CC $B Y)$. The use, distribution or reproduction in other forums is permitted, provided the original author(s) or licensor are credited and that the original publication in this journal is cited, in accordance with accepted academic practice. No use, distribution or reproduction is permitted which does not comply with these terms. 